\title{
A semantical interpretation of the post-electoral newspaper reporting in gaining the legitimacy from the citizens: a case study of the newspaper articles headlines during the post-electoral period
}

\author{
Wan Yusoff Wan Shaharuddin ${ }^{a}$, Soo-Yin See ${ }^{b}$ \\ Centre for Language Studies and Generic Development, \\ Universiti Malaysia Kelantan, Kelantan, Malaysia \\ E-mail address: ayusoff.ws@umk.edu.my; bsee@umk.edu.my
}

\begin{abstract}
Keywords: Semantical interpretation; newspapers; post-electoral period
\end{abstract}
\begin{abstract}
This qualitative study focuses on the semantical interpretation of the post-electoral newspaper reporting in gaining the legitimacy from the citizens. The study is being addressed through two research questions: 1) what are the semantical interpretation of the newspaper articles' headlines in the mainstream and the oppositions' newspapers? 2) What are the issues highlighted in the newspaper during the post-electoral period of the 13th General Election? The data for the entire research were obtained through the mainstream newspapers which are Utusan Malaysia, Kosmo and Harian Metro and also the opposition's newspaper represented by Harakah. The data were also collected based on the newspapers that were published after the Election Day has ended. However, the newspapers were not collected daily as the researcher has chosen a few newspapers that contained the traits of having portrayed electoral campaign. The data were analysed using the thematic analysis by deriving themes from the content analysis of the newspapers. The findings were divided into two sections which are semantical interpretations of newspaper articles' headlines during post-electoral period and issues highlighted in the political campaigns. The researcher has come to a conclusion that both mainstream and opposition based newspapers were portraying improper political headlines during the post-electoral period.
\end{abstract}

\section{INTRODUCTION}

The 13th General Election of Malaysia has come to a conclusion with the citizens of Malaysia has once again elected Barisan Nasional (BN) to lead the country. Under the leadership of Datuk Seri Najib Razak, BN managed to not only maintain most of the states that were under their governance, but also snatched back Kedah from the previous state government which is PanMalaysian Islamic Party (PAS). According to Harian Metro in its article on the 6th of May 2013, at least $70 \%$ out of the total $12,992,661$ registered voters have come out to perform their duty during the Election Day. In the process of gaining the people's trust, political campaigns were heavily executed throughout the country. Political parties spread words of their success and provided manifestos that are believed to be beneficial to the citizens of Malaysia. Such political campaigns can be seen in form of raising banners and flags, organizing political rally, distributing posters and even door-to-door visits done by the candidates competing in the 13th General Election.

Political campaigns can be considered as beginning when the election date is announced, the candidates' identity is publicized, the candidates are spending most of their time either to elected or to be re-elected and certain act of campaigns are being allowed or even being forbidden such as giving away money to gain the voters' support. One of the most influential medium in delivering political campaigns is the newspaper. By utilizing the newspaper, the style of political reporting can directly or indirectly helps to promote the significant value of the parties and even the candidate himself [7].

According to the Texas Ethics Commission (2011), political advertising can be defined as a form of communications which supports or opposes a candidate for nomination of either a public officer or a representative of a political party. Political advertising can be seen appearing on pamphlets, fliers, billboards, bumper stickers or even in any form of written materials. Other than 
that, political advertising are also being published in newspapers, magazines, broadcasted in radio, televisions and any forms of internet websites [28]. According to Ansolabehere and Iyengar (1995) in Berger (2011), political advertising is influential enough uninterested and unmotivated citizens who do not pay much attention in to other forms of campaign events such as political talks and debates between political candidates. Berger (2011) also mentioned that advertising is a medium that allow politicians to distribute their messages to a large number of people who are not particularly interested in political campaigns. Surprisingly, Berger (2011) has also come out to a conclusion that these uninterested people will usually easily be influenced by the political campaigns done in the form of political advertising. Berger (2011) pointed out that most political campaigns nowadays are utilizing negative approaches in order to gain support from the voters. In the Malaysian political sphere, such improper political advertising are being widely used in the mainstream tabloids. On the other hand, when issues such as the NFC (National Feedlot Corporation) scandal involving Dato' Seri Shahrizat Jalil emerged, the oppositions' based newspaper was presented with a huge opportunity to counter attack the mainstream tabloids which are virtually owned by the government. Another issue that will usually be highlighted by the opposition in most Malaysian based General Elections is the control of the media itself. As mentioned by Graber (2003) in Azizuddin (2009), governmental controls are common in any form of media. Thus, the Malaysian media sphere is believed to be controlled by the information that is supplied by government sources, giving government officials control over what to disclose or conceal and allowing them to present information from the government's perspective [4].

According to Miller (2005), theorists defined agenda setting as how the media could shape not only attitudes about issues, but perceptions about what issues are important. Miller (2005) also pointed out the three considerations of related agendas which are the media agenda, the public agenda and the policy agenda. The media agenda is a set of topics which are interpreted as important by the media source. Such sources can be in the form of newspapers, televisions and also the radio. On the other hand, Miller (2005) pointed out the public agenda as the set of topics that the members of the public believe to be important. The policy agenda can be defined as the issues pointed out by policy makers to be important [26]. Agenda-setting in the mass media has long been identified as causing certain topics, issues or even individuals to be "important" to us. In terms of political campaigns, Infante, Rancer and Womack (1997) explained that agenda-setting can help to extend the candidate's image to the public. Infante, et al (1997) also listed two important assumptions of agenda setting. The first assumption is reality is not being reflected by the media, whereas reality is actually being filtered and shaped. The second assumption lie on the premise of concentration by the media on a few issues leads the public to perceive those issues as much more important than the others [21].

According to the official website of the Election Commission of Malaysia (Suruhanjaya Pilihanraya Malaysia) or SPR, after the process of candidates' declaration has ended, the candidates were allowed to further their political campaigns by performing activities such as distributing posters, organizing political talks and even performing the traditional door-to-door campaign. A total of fees were required for the campaign to be commencing and political talks were required to obtain permits from the local authority. However, such activities which involve political campaigns must be executed before midnight, the day before the actual Election Day will be commencing. Nevertheless, although the General Election has long gone and the winning parties have already celebrated their victory, newspapers have been viewing political reports especially during the first week of the post-electoral period. According to Anuar (2005), during the 11th general elections, the Malaysian mainstream media were expected by the ruling government at that time which is the Barisan Nasional (BN) not only to publicize but also to promote to the whole country the achievements, particularly in the area of socioeconomic development resulting from the leadership of BN top leaders. However, the trend has been twisting nowadays since the 12th General Election which witnessed the fall of three prominent states which are Kedah, Selangor and Perak which was fortunately won back in a quite complicated manner. Since then, the mainstream newspapers are believed to be delivering political campaigns not only highlighting the strength of 
the government but also giving negatives description to the opposing parties. With the electoral campaign to be announced as ending at midnight of 5th May 2013, right before the Election Day, newspaper, either mainstream or opposition based were seen to be indirectly continuing the campaigns throughout the post-electoral period. Although the citizens of Malaysia have already delivered their votes, the post-electoral campaign implemented in the newspaper can be seen as a way of grabbing their attention in ensuring their continuous support of both the government and also the opposition.

Anuar (2005) listed a few major players in the mainstream media circulating all over Malaysia. First and foremost is The New Straits Times Press (M) Bhd (NSTP) which publishes main newspapers in Malaysia such as New Straits Times, Berita Harian and Harian Metro. The second major player in the local mainstream media is the Utusan Melayu (M) Bhd Group who owns Utusan Malaysia, Mingguan Malaysia and Kosmo. Both corporations were closely related to the dominant party of UMNO [1]. Therefore, Utusan Malaysia, Kosmo and Harian Metro were chosen as they represents the flagship of the mainstream media owns by the government itself. Harian Metro is the dominant product under the publication of NSTP. According to the official website of the NSTP Group (2013), 47\% of the Malay readers in the whole country are reading Harian Metro on a daily basis. On the other hand, Harakah is the official voice of Pan-Malaysian Islamic Party (PAS) and is owned by Jabatan Penerangan PAS Pusat [13]. Harakah pioneered the publication of oppositional flagged newspaper which was then followed by other forms of newspaper such as Suara Keadilan. The utilization of Harakah in this study is influential enough in avoiding bias and balancing the findings of the study. However, only the newspapers that were circulating during the first week of the post-electoral period were chosen in order to ensure the clarity of the data that will be collected.

There are a few studies that have already been done regarding to the political campaigns and the utilization of newspapers as one of the mediums in delivering the campaigns. Azizuddin (2009) mentioned about the situation in which the Malaysian media sphere is said to be controlled by the information that is supplied by government sources, giving government officials control over what to disclose or conceal and allowing them to present information from the government's perspective. Therefore, the study can help to further elicit the argument of how the mainstream media is believed to be portraying political headlines in their reporting. Nevertheless, the researcher has to avoid biasness in the study by utilizing a newspaper representing the opposition as well to indicate that newspaper has long been the tools of political campaigns regardless of whatever political parties that they are representing. However, this study will only be implying the form of headlines that appeared despite the results of the 13th General Election which has already been released. Therefore, the study can help readers to have an in-depth understanding of what form of campaigns done in significant with the post-electoral period. Thus, this study has been conducted to address the questions of: 1) what are the semantical interpretation of the newspaper articles' headlines in the mainstream and the oppositions' newspapers? 2) What are the issues highlighted in the newspaper during the post-electoral period of the 13th General Election?

\section{METHODOLOGY}

\subsection{The study setting and the subject}

The setting of the study is important in order to determine the level of information sufficiency that can be derived from the selected newspapers. In order to achieve maximum sufficiency in data collection, the research was conducted by utilizing the newspapers within the period of 6th May 2013, which is the day after the 13th General Election until 11th of May 2013. The dates were chosen to indicate the six days post-electoral period. The newspapers that were involved in this study are Harakah, Utusan Malaysia, Kosmo and Harian Metro. These newspapers were chosen as the subject of the study to determine the implementation of political campaign in the newspapers during the post-electoral period. The researcher has utilized the non-probability, with the purposive sampling as the specific method. This is because purposive sampling indicates that 
the units to be observed are selected on the basis of the researcher's judgement about which one will be the most useful or representative [5]. Therefore, the utilization of Harakah, Utusan Malaysia, Kosmo and Harian Metro will be most useful in conducting this research because these newspapers represent the flagship of particular political parties.

\subsection{Data gathering and analysis}

According to Lewis and Ritchie (2005), there are no set of rules in conducting a qualitative study. Therefore, the researcher has utilized the method of content analysis and also thematic analysis in coming out with the result of the study. According to Berelson (1952) and Robson (2002) in Lewis and Ritchie (2005), content analysis can be defined as the process of analysing the content and also the context of a document. Therefore, themes will be derived and presented within the frequency of it occurrence [24]. Other than that, the thematic analysis method was also utilized in order to further elicit the information derived from the newspapers' cuttings. According to Braun and Clarke (2006), thematic analysis can be defined as a qualitative analytic method for identifying, analysing and reporting themes or patterns within a set of data. Therefore, the researcher has performed the six steps listed by Braun and Clarke (2006) in conducting the thematic analysis which are:

1. Becoming familiar with the data by reading the data repeatedly, taking notes and marking ideas.

2. Generating initial codes by coming out with first list of ideas about what is in the data and what is appealing about them.

3. Searching for themes by re-focusing the analysis at the broader level of themes, rather than codes, categorizing different codes into prospective themes.

4. Reviewing themes by revising the set of candidate themes.

5. Defining and naming themes by defining and refining the themes that will be presented in the data analysis.

6. Producing the report with a set of fully worked-out themes and coming out with analysis and also the report.

The researcher has chosen three articles per day from the period of 6th May 2013 until 11th of May 2013 which indicate the post-electoral period after the 13th General Election. The articles were chosen randomly from Utusan Malaysia, Kosmo and Berita Harian which represented the flagship of the government. On the other hand, three articles were also chosen from Harakah which represents the opposition based newspaper. However, there were only six articles chosen as Harakah is not being published on a daily basis. Two Harakah Newspapers circulating from the 6th to 9th May and from 10th to 12th May were chosen in significant to the post-electoral period. The articles were then analyzed and essence and themes representing political campaign and issues highlighted during the post-electoral period were highlighted in findings and discussions.

\section{FINDINGS AND DISCUSSIONS}

\subsection{An approach to understand the semantical interpretation of the newspaper articles' headlines in the mainstream and the oppositions' newspapers: the development of themes}

The focus of this study is to discover and understand the implementation of political campaigns in the newspapers during the post-electoral period. In order to further elicit the study, the researcher has come out with themes in accordance to the implementation of political campaign during the post-electoral period in the mainstream newspapers which are Utusan Malaysia, Kosmo and Harian Metro as well as the opposition's newspaper which is represented by Harakah. The findings of the research were presented in accordance to the research questions to ensure that the themes derived are within the scope of political campaigns in the newspapers during the postelectoral period. 


\subsection{Semantical interpretation of the newspaper articles' headlines in the mainstream and also the oppositions' newspapers?}

There were eleven themes derived from the newspaper articles that were randomly chosen from Utusan Malaysia, Kosmo, Harian Metro and Harakah. Table 1 represents the themes that were derived from research question 1:

Table 1. Types of political campaigns in the post-electoral period: Harakah, Utusan Malaysia,

\begin{tabular}{|c|c|l|}
\multicolumn{2}{|c|}{ Kosmo and Harian Metro } \\
\hline Date & Newspaper & \multicolumn{1}{c|}{ Themes } \\
\hline $6^{\text {th }}$ May 2013 & Harian Metro & $\begin{array}{l}\text { Attacking the personality, highlighting support from celebrities, } \\
\text { portraying opposition's supporters aggressive actions }\end{array}$ \\
\hline $7^{\text {th }}$ May 2013 & Kosmo & $\begin{array}{l}\text { Remedying BN's defeat in the General Election, highlighting } \\
\text { disputes between members of the opposition parties, blaming } \\
\text { the Chinese Tsunami for BN's poor performance }\end{array}$ \\
\hline $8^{\text {th }}$ May 2013 & Utusan Malaysia & $\begin{array}{l}\text { Portraying the sentiment of ethnicity, blaming the oppositions' } \\
\text { provocative act }\end{array}$ \\
\hline $9^{\text {th }}$ May 2013 & Utusan Malaysia & Blaming the Chinese Tsunami for BN's poor performance \\
\hline $11^{\text {th }}$ May 2013 & Utusan Malaysia & $\begin{array}{l}\text { Highlighting disputes between members of the opposition } \\
\text { parties, attacking the personality, portraying opposition's } \\
\text { supporters aggressive actions }\end{array}$ \\
\hline $6-9^{\text {th }}$ May 2013 & Harakah & $\begin{array}{l}\text { Highlighting UMNO failure to defend the Malay, pointing out } \\
\text { deception in the General Election, attacking the personality }\end{array}$ \\
\hline $10-12^{\text {th }}$ May 2013 & Harakah & $\begin{array}{l}\text { Denying the phenomenon of Chinese Tsunami, pointing out } \\
\text { deception in the General Election }\end{array}$ \\
\hline
\end{tabular}

\section{i) Attacking the personality}

Kern (1989) in Berger (2011) explained that one of the examples of a negative political advertising can be seen in the campaigns that were not only attacking the political figures policies but also their characters and behaviours. Therefore, such form of political campaigns can lead to counterattacks which occur only in certain period within the campaigns [6]. The first theme of attacking the personality is aligned with the form of negative political advertising explained by Kern (1989) in Berger (2011). The theme was derived from the newspaper reporting entitled "Aishah questioned for not wearing purdah" (Harian Metro, $6^{\text {th }}$ May 2013). In the newspaper reporting, Harian Metro has portrayed Aishah as not showing the image of an Islamic candidate representing PAS, whereas all of her followers accompanying her were covering their face by wearing the purdah. The theme was also derived from another reporting entitled "Highlighting the sentiment of hatred towards the government although they have already won: Kit Siang continued to provoke" (Utusan Malaysia, $11^{\text {th }}$ May 2013). The article portrayed Lim Kits Siang, a top leader in DAP (Democratic Action Party) as provocative by insulting the prime minister and questioning the result of the $13^{\text {th }}$ General Election. Last but not least, the theme was also derived from the reporting entitled "Beware of Najib's final act, $4^{\text {th }}$ of May" (Harakah, 6-9 $9^{\text {th }}$ May 2013). The opposition tabloid portrayed the Prime Minister as manipulating the mainstream media such as RTM (Radio Televisyen Malaysia) in delivering his final premise in order to ensure the victory of $\mathrm{BN}$ in the General Election.

\section{ii) Highlighting support from celebrities}

The theme of highlighting support from celebrities was derived from a newspaper reporting entitled "Celebrities as the centre of attention: Iqram Dinzly, Mamat Khalid performing their responsibility" (Harian Metro, $6^{\text {th }}$ May 2013). The article portrayed Barisan Nasional (BN) as the choice of celebrities in the $13^{\text {th }}$ General Election. This is because the reporting has embedded the picture of Iqram Dinzly, a Malaysian actor, model and television host holding the banner of BN. 


\section{iii) Portraying opposition's supporters aggressive actions}

The third theme was derived from Harian Metro $6^{\text {th }}$ May 2013 entitled "Assaulted by five men: Two volunteers assaulted by the opposing supporters". The newspaper reporting mentioned about an incident whereby the supporters of a part went into their opposite members and attacked their base. Even though the political party that the attacker is supporting was not mentioned, the picture embedded with the report has shown clearly that the place of the attack was in a BN base camp which implies that the attacker is from the opposition and the victim is a supporter of BN. The second article in this theme is entitled "The 'black' gathering in front of SPR caused massive crowd to appear" (Utusan Malaysia, $11^{\text {th }}$ May 2013). The article portrayed the opposition's supporters as causing chaos by organizing demonstration in order to show their objection towards the result of the $13^{\text {th }}$ General Election.

\section{iv) Remedying BN's defeat in the General Election}

The fourth theme was derived from the newspaper reporting entitled "13 Pasir Gudang MCA members resigned" (Kosmo, $7^{\text {th }}$ May 2013). The reporting highlighted the act of 13 MCA (Malaysian Chinese Association) members in Pasir Gudang who decided to step down from their posts due to the poor performance of the party in the $13^{\text {th }}$ General Election.

\section{v) Highlighting dispute between members of the opposition parties}

The fifth theme was derived from the newspaper reporting entitled "The dispute to become the State Minister of Selangor" (Kosmo, $7^{\text {th }}$ May 2013). The article was highlighting PAS as having the right to take the MB position in the Selangor state government. However, the previous holder was from PKR. Therefore this form of article can point out the defectiveness of the opposition's top leaders. Another article portraying the dispute within the opposition's members is entitled "Azmin questioned Anwar's credibility" (Utusan Malaysia, $11^{\text {th }}$ May 2013).

\section{vi) Blaming the Chinese Tsunami for BN's poor performance}

The theme of blaming Chinese Tsunami for BN's poor performance was derived from four newspaper reporting on the $7^{\text {th }}$ and $9^{\text {th }}$ of May 2013. The first headline was Kosmo $\left(7^{\text {th }}\right.$ May 2013) entitled "Pretending to support the governments' programme but eventually launching the Chinese Tsunami during the $13^{\text {th }}$ General Election: Chinese voters were not sincere". Such newspaper reporting indicates that the poor performance of $\mathrm{BN}$ within the location with the density of Chinese population has caused them to suffer major lost. Other articles that were found to possess the same theme are "Chinese voters trapped themselves: non-Malay, PM, BN has a good reason to be frustrated" (Utusan Malaysia, $9^{\mathrm{th}}$ May 2013), "The effort to support the Chinese community was not appreciated: Najib got a point of frustration" (Utusan Malaysia, $9^{\text {th }}$ May 2013) and "They have sent the wrong message to the government: Chinese voters trapped themselves" (Utusan Malaysia, $9^{\text {th }}$ May 2013).

\section{vii) Portraying the sentiment of ethnicity}

The theme above was derived from the newspaper reporting entitled "DAP massive win in the General Election: Malay need to be united" (Utusan Malaysia, $8^{\text {th }}$ May 2013). The article portraying the impact of Chinese Tsunami on the $13^{\text {th }}$ General Election was strengthen with the comments given by the former Secretary of Penang's DAP (Democratic Action Party), Mohemed Razali Abdul Rahman. 


\section{viii) Blaming the opposition for being provocative}

The theme above was derived from the newspaper reporting entitled "Who started the provocation: DAP launched massive programs throughout the social media, disseminating pamphlets" (Utusan Malaysia, $8^{\text {th }}$ May 2013). The article was written in order to point out the provocative act of the opposition in persuading the Chinese to direct their votes from MCA (Malaysian Chinese Association) to DAP (Democratic Action Party). The headlines also shown a few examples of the activities perform in provoking the public to vote the opposition.

\section{ix) Highlighting UMNO failure in defending the Malay}

The theme above was derived from the newspaper reporting entitled "The evidence of UMNO's betrayal towards the Malay" (Harakah, 6-9 ${ }^{\text {th }}$ May, 2013). The article highlights UMNO's conspiracy and failure in assisting the Malays.

\section{x) Pointing out deception in the General Election}

The theme above was derived from the newspaper reporting entitled "MAS, Air Asia need to come out with a statement" (Harakah, 6-9 ${ }^{\text {th }}$ May, 2013). The article highlighted the issue of MAS (Malaysia Airline System) and Air Asia arranging flights for 40,500 passengers from the Sabah and Sarawak to the Peninsular Malaysia. Another two articles entitled "Deception: Pakatan did not accept the result, asking for explanation" (Harakah, 10-12 $2^{\text {th }}$ May 2013) and "Permanent ink: SPR need to come out with an official statement" (Harakah, 10-12 $2^{\text {th }}$ May 2013) were also highlighting the issues of deception such as the permanent ink and ghost voters in the latest General Election.

\section{xi) Denying the phenomenon of Chinese Tsunami}

The theme above was derived from the newspaper reporting entitled "Not the Chinese Tsunami" (Harakah, 10-12 ${ }^{\text {th }}$ May 2013). The article was indicating that the BN's poor performances was not because of the Chinese voters but because of the Malaysian voters were selecting Pakatan Rakyat (The People' Alliance) as a whole. Such indicator was made in order to deny the blame that $\mathrm{BN}$ has portrayed on the Chinese.

\subsection{Issue highlighted in the newspaper articles' headlines}

Other than that, there were also some new issues arise after the end the $13^{\text {th }}$ General Election. The shocking defeat of most BN's candidates to the DAP (Democratic Action Party) candidates has caused several new issues to emerge.

Table 2. Issue highlighted in the political campaigns

\begin{tabular}{|c|c|l|}
\hline Date & Newspaper & \multicolumn{1}{c|}{ Themes } \\
\hline $6^{\text {th }}$ May 2013 & Harian Metro & No new issue \\
\hline $7^{\text {th }}$ May 2013 & Kosmo & The Chinese Tsunami, disputes in the Selangor state government \\
\hline $8^{\text {th }}$ May 2013 & Utusan Malaysia & The Chinese Tsunami \\
\hline $9^{\text {th }}$ May 2013 & Utusan Malaysia & The Chinese Tsunami \\
\hline $11^{\text {th }}$ May 2013 & Utusan Malaysia & Conflict in the Selangor state government \\
\hline $6-9^{\text {th }}$ May 2013 & Harakah & Deception in the General Election \\
\hline $10-12^{\text {th }}$ May 2013 & Harakah & Chinese Tsunami, Deception in the General Election \\
\hline
\end{tabular}




\section{i) The Chinese tsunami}

The theme of Chinese Tsunami was derived from a few articles written in Utusan Malaysia, Kosmo, Harian Metro and Harakah. The first headline was from Kosmo ( $7^{\text {th }}$ May 2013) entitled "Pretending to support the governments' programme but eventually launching the Chinese Tsunami during the $13^{\text {th }}$ General Election: Chinese voters were not sincere". Such newspaper reporting indicates that the poor performance of $\mathrm{BN}$ within the location with the density of Chinese population has caused them to suffer major lost. Other articles that were found to possess the same theme are "DAP massive win in the General Election: Malay need to be united" (Utusan Malaysia, $8^{\text {th }}$ May 2013), "Chinese voters trapped themselves: non-Malay, PM, BN has a good reason to be frustrated" (Utusan Malaysia, $9^{\text {th }}$ May 2013), "The effort to support the Chinese community was not appreciated: Najib got a point of frustration" (Utusan Malaysia, $9^{\text {th }}$ May 2013), "They have sent the wrong message to the government: Chinese voters trapped themselves" (Utusan Malaysia, $9^{\text {th }}$ May 2013) and "Not the Chinese Tsunami" (Harakah, 10-12 $2^{\text {th }}$ May 2013).

\section{ii) Conflict in the Selangor state government}

The theme of conflict in the Selangor state government is another theme indicating the issues highlighted from the $13^{\text {th }}$ General Election. The theme was derived from the newspaper reporting entitled "The dispute to become the State Minister of Selangor" (Kosmo, $7^{\text {th }}$ May 2013). The article was highlighting PAS as having the right to take the MB position in the Selangor state government. However, the previous holder was from PKR. Therefore this form of article can point out the defectiveness of the opposition's top leaders. Another article portraying the dispute within the opposition's members is entitled “Azmin questioned Anwar's credibility" (Utusan Malaysia, 11 May 2013).

\section{iii) Deception in the General Election}

The theme above was derived from the newspaper reporting entitled "MAS, Air Asia need to come out with a statement" (Harakah, 6-9 ${ }^{\text {th }}$ May, 2013). The article highlighted the issue of MAS and Air Asia arranging flights for 40,500 passengers from the Sabah and Sarawak to the Peninsular Malaysia. Another two articles entitled "Deception: Pakatan did not accept the result, asking for explanation" (Harakah, 10-12 ${ }^{\text {th }}$ May 2013) and "Permanent ink: SPR need to come out with an official statement" (Harakah, 10-12 ${ }^{\text {th }}$ May 2013) were also highlighting the issues of deception such as the permanent ink and ghost voters in the latest General Election.

\section{CONCLUSION}

In the process of analysing the implementation of political campaign in the newspapers during the post-electoral period, the researcher has come out with a few conclusions. First and foremost, the researcher has found out that although the political campaign period has ended, the newspaper, both mainstream and opposition based newspaper were seen to be utilized in spreading the political belief. Other than that, the researcher also has found out that the issue of Chinese Tsunami and deception in the 13th General Election were highlighted as the main issues throughout the post-electoral week. In that case, the Agenda Setting Theory has been implemented by the newspaper in the process of leaving something for the readers to think of. According to Miller (2005), theorists defined agenda setting as how the media could shape not only attitudes about issues, but perceptions about what issues are important. Therefore, the issue of Chinese Tsunami has left the other races especially the Malay and Bumiputera to perceive Chinese as supporting DAP (Democratic Action Party), thus causing them to be paranoid of losing their rights and specialties of the Bumiputera. However, the opposition-based tabloid has also managed to implement the Agenda Setting Theory by leaving question marks regarding to the conspiracy in the 
13th general Election. Article such as "Deception: Pakatan did not accept the result, asking for explanation" (Harakah, 10-12 $2^{\text {th }}$ May 2013) and "Permanent ink: SPR need to come out with an official statement" (Harakah, 10-12 ${ }^{\text {th }}$ May 2013) were highlighting the issues of deception such as the permanent ink and ghost voters in the latest General Election.

\section{IMPLICATIONS}

According to Wariya (2011), one of the principles in the Journalism Code of Ethics in Malaysia is "journalists should avoid news that are racist in nature, extreme and contrary to the Malaysian plural society". Therefore, this study can help to guide the journalist in avoiding them from portraying racial related headlines in their news reporting. Other than that, the study can also help the Election Commission of Malaysia (SPR) to come out with a proper guideline in ensuring that political campaign period will be fully defective at midnight before the General Election Day.

\section{RECOMMENDATION}

There are some recommendations that can be implemented in order to improvise future researches. First and foremost, a similar study can be conducted by implementing the quantitative method in order to get more views from larger amount of respondents. Therefore, questionnaires can be formulated from the implementation of the Agenda Setting Theory in order to help the quantitative researcher to understand the implementation of political campaigns in the newspaper during the post-electoral period. Besides, the period of the study can also be changed into the period of before the General Election. Therefore, future researcher will have the priority of understanding political campaigns implementation in the newspapers before the General Election.

\section{References}

[1] Anuar, M.K (2005). Politics and the Media in Malaysia. Philippine Journal of the Third World Studies, 20 (1), 25-47.

[2] Anwar (2013, 6-9 May). Bukti UMNO khianati Melayu [The evidence of UMNO's betrayal towards the Malay]. Harakah, p.3.

[3] Aziz (2013, 10-12 May). Bukan Tsunami Cina [Not the Chinese Tsunami]. Harakah, p.8.

[4] Azizuddin, M (2009). The public sphere and media politics in Malaysia. Newcastle: Cambridge Scholars Publishing.

[5] Babbie, E. (2010). The practice of social research. Canada: Wadsworth.

[6] Berger, A.A (2011). Ads, Fads and Consumer Culture: Advertising's Impact on American Character and Society. Plymouth: Rowman and Littlefield Publishers.

[7] Brady, H.E., Johnston, R. \& Sides, J. (2008). The Study of Political Campaigns. Retrieved June 9, 2013, from The George Washington University Official Web site: http://www.gwu.edu/

[8] Braun, V., \& Clarke, V. (2006) Using thematic analysis in psychology. Qualitative Research in Psychology, 3 (2). pp. 77-101.

[9] Election Commission of Malaysia (2013), Proses Pilihanraya. Retrieved June 9, 2013, from The Election Commission Official Web site: http://www.spr.gov.my/spr2012/

[10]Faizal (2013, 10-12 May). Penipuan: Pakatan tolak keputusan, tuntut penjelasan [Deception: Pakatan did not accept the result, asking for explanation]. Harakah, p.3.

[11]Hamimah (2013, May 9). Mereka beri mesej salah kepada kerajaan BN: Pengundi Cina jerat diri sendiri [They have sent the wrong message to the government: Chinese voters trapped themselves]. Utusan Malaysia, p.9. 
[12]Hamimah (2013, May 11). Main sentimen kebencian rakyat walaupun menang besar: Kit Siang teruskan provokasi [Highlighting the sentiment of hatred towards the government although they have already won: Kit Siang continued to provoke]. Utusan Malaysia, p.4.

[13] Harakahdaily (2013). About Us. Retrieved June 9, 2013, from Harakahdaily Official Web site: http://en.harakahdaily.net/index.php/home.html

[14] Harakah (2013, 6-9 May). MAS, Air Asia didesak beri penjelasan segera [MAS, Air Asia need to come out with a statement]. Harakah, p.3.

[15] Harakah (2013, 6-9 May). Hati-hati rayuan terakhir Najib, 4 Mei [Beware of Najib's final act, $4^{\text {th }}$ of May]. Harakah, p.3.

[16] Harian Metro (2013, May 6). Aishah dipersoal tak berpurdah Aishah questioned for not wearing purdah]. Harian Metro, p.6.

[17] Harian Metro (2013, May 6). Artis tarik perhatian: Iqram Dinzly, Mamat Khalid laksana tanggungjawab [Celebrities as the centre of attention: Iqram Dinzly, Mamat Khalid performing their responsibility]. Harian Metro, p.9.

[18] Harian Metro (2013, May 6). Cedera dibelasah lima lelaki: Dua petugas parti politik diserang guna topi keledar oleh penyokong lawan [Assaulted by five men: Two volunteers assaulted by the opposing supporters]. Harian Metro, p.22.

[19] Harian Metro (2013, 6 May). Sekurang-kurangnya 70\% keluar mengundi. Harian Metro, p.6.

[20]Hornsby, A.S. (2005). Oxford advanced learner's dictionary of current English. Oxford: Oxford University Press.

[21] Infante, D.C., Rancer, A.S. \& Womack, D.F. (1997). Building communication theory. Illinois. Waveland Press.

[22] Kosmo (2013, May 7). 13 ahli MCA Pasir Gudang letak jawatan [13 Pasir Gudang MCA members resigned]. Kosmo, p.5

[23] Kosmo (2013, May 7). Pura-pura sokong program kerajaan tetapi lancarkan Tsunami Cina pada PRU-13: Pengundi Cina bersikap talam dua muka [Pretending to support the governments' programme but eventually launching the Chinese Tsunami during the $13^{\text {th }}$ General Election: Chinese voters were not sincere]. Kosmo, p.1

[24]Lewis, J., \& Ritchie, J. (2005). Qualitative research practice: a guide for social science students and researchers. Thousand Oaks: Sage Pub.

[25] Megat Ramli (2013, May 7). Perebutan untuk menjadi Menteri Besar Selangor: Pasca PRU-13 [The dispute to become the State Minister of Selangor]. Kosmo, p.6

[26]Miller, K (2005). Communication theories: perspectives, processes, and contexts. New York. McGraw-Hill.

[27] Sofian (2013, May 9). Segala usaha mengangkat kehidupan masyarakat Cina dipandang sepi: kekecewaan Najib berasas [The effort to support the Chinese community was not appreciated: Najib got a point of frustration]. Utusan Malaysia, p.6.

[28] Texas Ethics Commission (2011). Political Advertising: What You Need to Know? Retrieved June 9, 2013, from The Texas Ethics Commission Official Web site: http://www.ethics.state.tx.us/

[29] Utusan Malaysia (2013, May 8). Kemenangan besar DAP: Melayu perlu bersatu [DAP massive win in the General Election: Malay need to be united]. Utusan Malaysia, p.6. 
[30]Utusan Malaysia (2013, May 9). Reaksi pelbagai pihak bukan Melayu, PM, BN ada sebab untuk kecewa: Pengundi Cina jerat diri [Chinese voters trapped themselves: non-Malay, PM, $\mathrm{BN}$ has a good reason to be frustrated]. Utusan Malaysia, p.3.

[31]Utusan Malaysia (2013, May 11). Azmin persoal Anwar [“Azmin questioned Anwar's credibility"]. Utusan Malaysia, p.1.

[32] Utusan Malaysia (2013, May 11). Perhimpunan hitam depan SPR cetus kesesakan [The 'black' gathering in front of SPR caused massive crowd to appear]. Utusan Malaysia, p.4

[33]Wan Nordin (2013, 10-12 May). Dakwat kekal, SPR harus beri penjelasan [Permanent ink: SPR need to come out with an official statement]. Harakah, p.3.

[34] Wariya, C (2011). Journalism code of ethics Malaysia. Selangor: Media Global Matrix.

[35]Zulkiflee (2013, May 8). DAP lancar gerakan provokasi secara tersusun, luar biasa melalui media sosial, risalah: Siapa dulu memulakan provokasi? [Who started the provocation: DAP launched massive programs throughout the social media, disseminating pamphlets] Utusan Malaysia, p.11. 